\title{
Endothelial Progenitor Cells in Chronic Renal Insufficiency
}

\author{
Kay Herbrig Frank Pistrosch Sarah Foerster Peter Gross \\ Division of Nephrology, Department of Internal Medicine III, Technical University of Dresden, Dresden, Germany
}

\section{Key Words}

Endothelial progenitor cells - Atherosclerosis .

End-stage renal disease $\cdot$ Chronic renal insufficiency

\begin{abstract}
There is growing evidence for a role of endothelial progenitor cells (EPCs) in the repair of damaged endothelium. It remains unclear which cell populations are most useful for clinical trials. Administration of drugs increasing EPC numbers and/or improving functional properties seems attractive. Further basic research is necessary to understand the mechanisms of mobilization, differentiation and homing of EPC in general and in particular under uremic conditions. Nephrologists should search for strategies to ameliorate EPC dysfunction of uremia. In this way it might be possible to test whether improved EPC biology is associated with decreased cardiovascular mortality in uremic humans. In any such studies the difficulties are going to be related to the complex procedures for EPC isolation, the testing of their identity and differentiation and their propagation before use.
\end{abstract}

Copyright $\odot 2006$ S. Karger AG, Basel

Until about 1990, the vascular endothelium was considered to be an inactive tissue that covered the inside of blood vessels. In case of trauma it was held that repair of endothelium would occur by endothelial cells (ECs) proliferating from the margins of the endothelial wound towards the center eventually covering the entire defect.

\section{The Concept of Endothelial Repair by Endothelial Progenitor Cells}

All this has changed dramatically in the last $8-10$ years. On the one hand, it was discovered that endothelium is a highly active structure, capable of participating in the regulation of vasoconstriction, blood coagulation, smooth muscle cell proliferation, vascular permeability and stickiness of the endothelial surface (via expression of adhesion molecules) [1]. On the other hand, it has become highly likely that circulating endothelial progenitor cells (EPCs), derived from bone marrow hematopoietic stem cells (HSC), may function as vascular 'repair cells' - together with local progenitor cells [2].

A seminal observation was reported by Asahara et al. [2] in 1997. They investigated the hypothesis that peripheral blood contains progenitor cells that can differentiate into mature ECs. They showed that mononuclear blood cells positive for the HSC markers CD34 and Flk-1 (a receptor for vascular endothelial growth factor) are cells with an ability to assume an endothelial phenotype in vitro. This was demonstrated by their expression of EC markers CD31, E-selectin, Flk-1, cNOS and Ulex europaeus agglutinin-1. Another landmark study was performed by Shi et al. [3]. In their model in the dog they showed that implanted Dacron grafts were rapidly covered by bone marrow-derived CD $34^{+}$HSCs.

Subsequently it became clear that there was a need to differentiate these cells further. It was proposed to distinguish between stem cells, EPCs and mature ECs, and cellular surface markers came to be used towards these ends.

\section{KARGER \\ Fax +4161306 1234 E-Mail karger@karger.ch} www.karger.com
(C) 2006 S. Karger AG, Basel 1420-4096/06/0291-0024\$23.50/0

Accessible online at: www.karger.com/kbr
Kay Herbrig

Division of Nephrology, Department of Internal Medicine III

Universitätsklinikum C.G. Carus, Dresden

Fetscherstrasse 74, DE-01307 Dresden (Germany)

Tel. +49 351458 3473, Fax +493514466376, E-Mail kayherbrig@web.de 
It was expected that these methods would enable researchers to follow EPCs in the vessel wall, for instance an issue of particular relevance to this publication. Unfortunately, this has remained a difficult and somewhat controversial area - even in 2006.

At this time the problem is that researchers have not yet reached consensus on the validity of specific markers. Given these caveats, we would like to summarize the present state as follows. It is generally accepted that HSCs in peripheral venous blood (i.e. cells characterized by the cell surface markers CD34 and CD133) have a potential to mature into ECs in vivo [4-6]. However, their numbers in the circulation are exceedingly small $(0.005-0.05 \%$ of circulating MNC). This is an important limitation in any 'therapeutic endeavors' involving circulating HSCs. Larger numbers of these cells may be generated in peripheral venous blood only by mobilization from the bone marrow inducible through granulocyte colony-stimulating factor or proinflammatory cytokines [7]. Such treatments carry a certain risk of adverse events [8].

In different studies it was possible to identify yet other cell populations in the peripheral blood that expressed endothelial marker proteins and assumed functions of angiogenic ECs following ex vivo expansion [9-15]. For instance, $\mathrm{CD} 14^{+}$mononuclear cells (marker for monocytes) with these properties were found to have functional features comparable to EPCs generated from HSCs [10]. Hence, these cells are now considered to be EPCs as well. In these EPCs, the vascular endothelial growth factor receptor-2 (VEGF-R2, also called kinase insert domain receptor) seem to possess a key role in their differentiation to the mature endothelial phenotype [13]. A very recent study described a population of $\mathrm{CD}^{4} 4^{+} /$ $\mathrm{CD} 34^{\text {low }}$ cells as the major source of circulating progenitors [14]. These cells are characterized by the monocytic antigen CD14 and the expression of CD34 at a low level only detectable by a highly-sensitive antibody-conjungated magnetofluorescent liposome technique. The level of these cells in peripheral venous blood was reported as $0.6-8.5 \%$ of all white blood cells.

A third important source of EPCs besides HSCs and monocytic populations are circulating mesenchymal stem cells [15]. A diagram illustrating the present hypothesis of endothelial wound repair by circulating EPCs is shown in figure 1.

The situation may be more multifaceted than described so far however. There are several discrepant reports in the literature. Ziegelhoeffer et al. $[16,17]$ tested the hypothesis of incorporation of bone marrow-derived cells into adult growing vessels. The authors did not find any incorporation of bone marrow-derived cells into the endothelium of growing vessels. However, bone marrowderived cells did accumulate in perivascular areas of collateral arterial growth. The cells stained positive for growth factors and chemokines. Their capability to promote vascular growth was unrelated to their cellular incorporation into the endothelium; instead it appeared attributable to paracrine effects. Comparable results were also reported by other groups [18, 19].

We would like to point here that the processes of mobilization and homing of EPCs have been reviewed extensively by Aicher et al. [7] and Urbich and Dimmeler [20] will not be discussed in detail here.

\section{Enumeration of Endothelial Progenitor Cells in Humans}

There are two general strategies to estimate the levels of EPCs in humans (i.e. peripheral hematopoietic, MNCderived and mesenchymal EPCs together). The first one involves direct measurement of putative precursor cell populations in peripheral blood by flow cytometric analysis. The limitations of this approach are the very small numbers of circulating EPCs. In addition, the uncertainties surrounding the specificity and applicability of surface markers hampers this method. Most researchers using the direct measurement count $\mathrm{CD} 45^{+} / \mathrm{CD} 34^{+}$HSCs. Other investigators attempt to count certain subpopulations of the former class of HSCs (e.g. CD $34^{+} / \mathrm{VEGF}-\mathrm{R} 2^{+}$; $\mathrm{CD} 34^{+} / \mathrm{CD}_{133^{+}}$; $\mathrm{CD} 34^{+} / \mathrm{CD} 133^{+} / \mathrm{VEGF}-\mathrm{R} 2^{+}$populations). These HSC subpopulations account for no more than $0.005-0.05 \%$ of all mononuclear cells in peripheral blood. It follows without saying that no functional testing is possible on such minuscule cellular fractions.

The second approach to an 'enumeration' of EPCs is via cultivation. These techniques focus on the ability of peripheral blood mononuclear cells to differentiate into cells with an endothelial phenotype.

The principle of this method is as follows: (a) cultivation of peripheral blood mononuclear cells and selection of those that adhere to fibronectin-covered culture dishes, and (b) further propagation and testing of the selected cells - since it is known that they develop an endothelial phenotype under defined cell culture conditions (supplementation of the cell culture medium with VEGF, HGF and bFGF). The exact origin of these cultured EPCs cannot be determined clearly in this way. The common methods of EPC estimation in human peripheral blood are shown in figure 2 . 

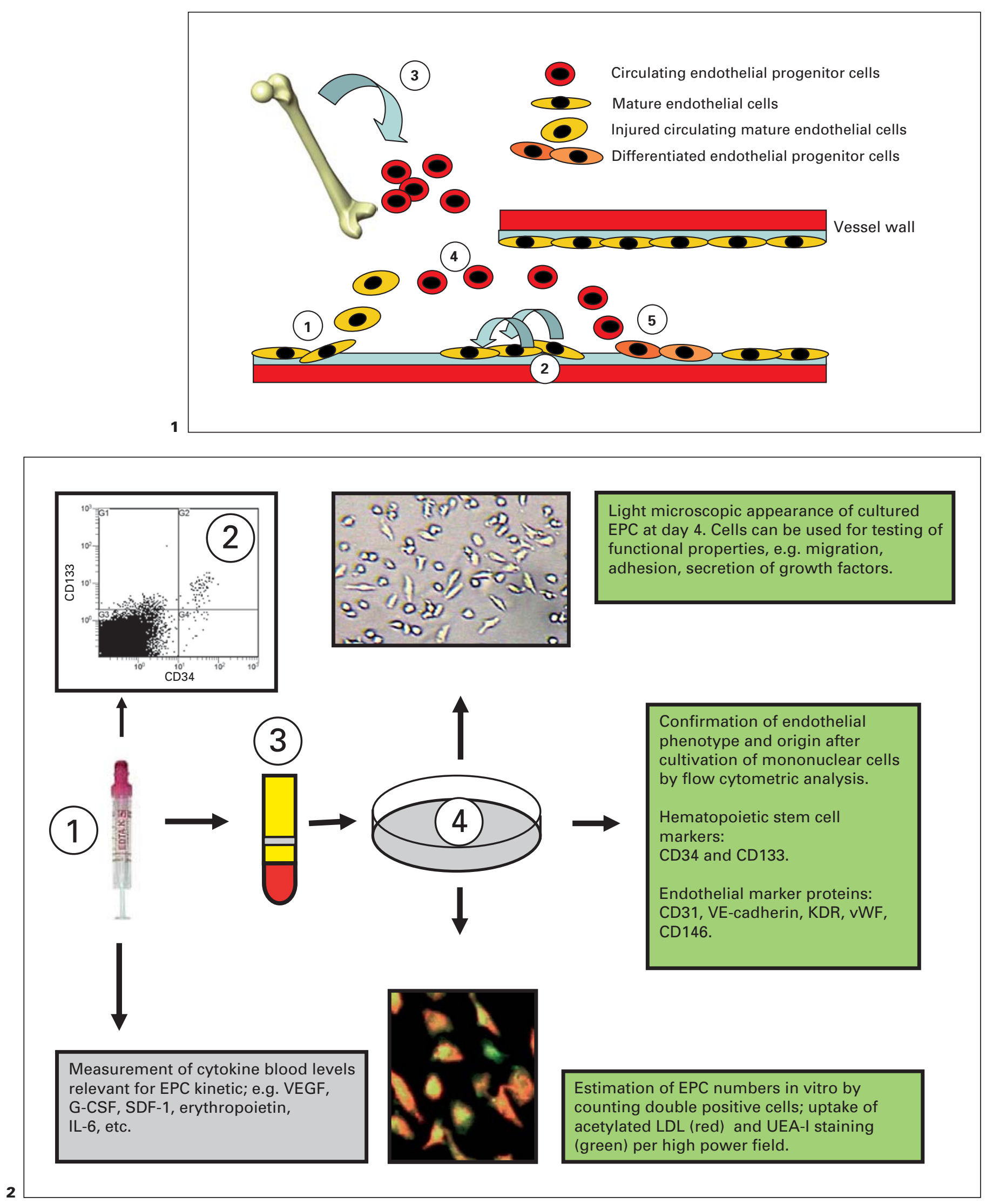
Nonetheless, an advantage of the cultivation approach is the higher number of EPCs after a short period of cultivation. This facilitates further experimentation. Thus, multiple functional properties may be tested, e.g. migratory activity in response to different chemoattractant agents, tube formation in matrigel as an in vitro model for angiogenesis, adherence to mature ECs or to components of the extracellular matrix as one aspect of the homing of EPCs to sites of endothelial injury or to a denuded vessel wall. However, caution is needed in the interpretation of any results. These cells have been propagated in vitro, i.e. under artificial conditions. For example it is known that the specific type of the coating of culture dishes may have effects of its own on the adherent cells. In culture assays using fibronectin this variable will tend to overestimate EPCs of patients that received treatments with statins. Therapy with statins increases the expression of matrix adhesion molecules in mononuclear cells with subsequently increased adherence to fibronectin [20] and this may apply to EPCs too. Another 'abnormality' is that the concentrations of growth factors necessary to induce any proliferational differentiation of MNC derived EPCs into an endothelial phenotype are up to 100fold higher than in vivo. On the other hand, EPCs generated in this way may have exciting therapeutic potential [21-26]. For example, in animal models of ischemia these cells homed to the injured endothelium and improved neovascularization in the ischemic region [2124]. Autologous transplantation after ex vivo expansion and cultivation of MNCs followed by differentiation to EPCs and autologous transplantation apparently re-

Fig. 1. Diagram showing present hypotheses of endothelial wound repair involving EPCs: (1) endothelial injury and dislodged, 'shed' ECs; (2) replacement of lost ECs by adjacent dividing mature ECs; (3) mobilization of EPC from bone marrow; (4) homing of EPC to sites of endothelial damage, and (5) repair of the endothelial wound by incorporation of EPC and further endothelial differentiation.

Fig. 2. Diagram summarizing common methods of EPC estimation in human peripheral blood. Peripheral blood samples (1) can be used for direct measurement of circulating EPC precursor populations by flow cytometric analysis (2), separation of plasma or serum for estimation of cytokine levels and/or transferred to isolation of mononuclear cells by density gradient centrifugation (3). Cultivation of mononuclear cells under cell culture conditions optimized for growth of ECs leads to differentiation of mononuclear cells to endothelial progenitor cells (4) and the possibility to further investigations in vitro.

Endothelial Progenitor Cells in Chronic Renal Insufficiency duced ischemic injury after myocardial infarction in humans [24].

Taken together, there is no consensus on how to measure EPC levels reliably. It is still unclear which stem/progenitor cell population has the highest impact on neovascularization, angiogenesis or endothelial repair in vivo and how such involvement takes place (direct incorporation into the endothelium or paracrine effects of stem cells in perivascular tissue).

This is a rapidly growing field. The results of future studies hopefully will shed more light on these issues. In the meantime, caution is appropriate to prevent overinterpretation of any results.

\section{Endothelial Progenitor Cells and Atherosclerosis}

The role of EPCs in atherosclerosis is currently an area of active investigation; not surprisingly, available findings appear to be incomplete and preliminary. Several reports have dealt with atherosclerosis. It was demonstrated in animal models that EPCs home to denuded vessel walls and atherosclerotic lesions. These functions contributed to the preservation of an intact endothelial layer in animal models. For example, Walter et al. [27] studied a model of carotid artery balloon injury. They demonstrated that bone marrow-derived cells contributed substantially to endothelial repair. Interestingly, the findings of Walter et al. imply also that EPCs respond to - as yet unknown - homing signals to areas of trauma and denudation. In another study, Griese et al. [25] reported that ex vivo expanded $\mathrm{CD}_{3}{ }^{+}$mononuclear cells derived from peripheral blood led to rapid re-endothelialization of denuded vessels and graft segments in rabbits. Hu et al. [26] showed that endothelial replacement in allogenic aortic transplants in mice occurred by bone marrow-derived progenitor cells of the recipient. As reported by Rauscher et al. [28], transplantation of wild-type bone marrow to $\mathrm{ApoE}^{-/-}$mice reduced the formation of atherosclerotic lesions. The latter study also pointed to a role of aging and progenitor cell exhaustion in certain situations. Only progenitor cells from young animals had preventive effects in terms of atherosclerosis.

A potential of EPCs in vascular protection in humans was also suggested by the association between EPCs and risk factors for atherosclerosis [29]. Thus, the numbers of EPCs were found to be low in patients with a high degree of coronary artery disease [30]. Age, smoking, diabetes 
Table 1. Clinical pilot studies estimating EPC numbers and/or function in different states of renal insufficiency and end-stage renal failure

\begin{tabular}{|c|c|c|c|c|}
\hline $\begin{array}{l}\text { Study subjects/ } \\
\text { stage of CRF }\end{array}$ & $\begin{array}{l}\text { Circulating precursor } \\
\text { populations }\end{array}$ & $\mathrm{EPC}$ number in vitro & $\begin{array}{l}\text { EPC function } \\
\text { in vitro }\end{array}$ & $\begin{array}{l}\text { Group } \\
\text { (first author) }\end{array}$ \\
\hline $\begin{array}{l}\text { Hemodialysis patients } \\
(\mathrm{n}=50)\end{array}$ & $\begin{array}{l}\mathrm{CD} 45^{+} / \mathrm{CD} 34^{+} \downarrow \\
\mathrm{CD} 45^{+} / \mathrm{AC} 133^{+} \downarrow\end{array}$ & $-41 \%$ vs. control & Not done & $\begin{array}{l}\text { Eizawa } \\
2003[43]\end{array}$ \\
\hline $\begin{array}{l}\text { Advanced renal } \\
\text { insufficiency }(n=8)\end{array}$ & $\mathrm{CD} 45^{+} / \mathrm{CD} 34^{+} \downarrow$ & $-45 \%$ vs. control & $\begin{array}{l}\text { Tube formation } \uparrow \\
\text { (after darbepoietin treatment) }\end{array}$ & $\begin{array}{l}\text { Bahlmann } \\
2003[46]\end{array}$ \\
\hline $\begin{array}{l}\text { Advanced renal insuffi- } \\
\text { ciency - effect of rhEPO } \\
\text { treatment }(n=11)\end{array}$ & $\begin{array}{l}\mathrm{CD} 45^{+} / \mathrm{CD} 34^{+} \uparrow \\
\text { after rhEPO treatment }\end{array}$ & $\begin{array}{l}\text { Up to } 312 \% \text { vs. before } \\
\text { rhEPO treatment }\end{array}$ & $\begin{array}{l}\text { Tube formation } \uparrow \\
\text { (after rhEPO treatment) }\end{array}$ & $\begin{array}{l}\text { Bahlmann } \\
2004 \text { [45] }\end{array}$ \\
\hline $\begin{array}{l}\text { Advanced renal insuffi- } \\
\text { ciency }(\mathrm{n}=46)\end{array}$ & $\begin{array}{l}\mathrm{CD} 45^{+} / \mathrm{CD} 34^{+} \\
\text {no difference compared } \\
\text { to healthy control }\end{array}$ & $-29 \%$ vs. control & $\begin{array}{l}\text { Tube formation and migratory } \\
\text { capacity } \downarrow \text { (effect of uremic serum } \\
\text { on EPC derived from control) }\end{array}$ & $\begin{array}{l}\text { de Groot } \\
2004[48]\end{array}$ \\
\hline $\begin{array}{l}\text { End-stage renal disease } \\
(\mathrm{n}=6)\end{array}$ & $\begin{array}{l}\text { No significant increase } \\
\text { of CD } 45^{+} / \mathrm{CD} 34^{+} \text {after } \\
\text { begin of dialysis }\end{array}$ & $\begin{array}{l}-20 \% \text { vs. control } \\
+17 \% \text { (after institution } \\
\text { of dialysis) vs. control }\end{array}$ & Not done & $\begin{array}{l}\text { de Groot } \\
2004[48]\end{array}$ \\
\hline $\begin{array}{l}\text { Hemodialysis patients } \\
(\mathrm{n}=20)\end{array}$ & $\begin{array}{l}\mathrm{CD} 45^{+} / \mathrm{CD} 34^{+} \downarrow \\
\mathrm{CD} 45^{+} / \mathrm{CD} 34^{+} / \mathrm{CD} 133^{+} \downarrow\end{array}$ & $+26 \%$ vs. control & $\begin{array}{l}\text { Migratory capacity } \downarrow \\
\text { Adhesion to mature EC } \downarrow \\
\text { Adhesion to ECM } \downarrow\end{array}$ & $\begin{array}{l}\text { Herbrig } \\
2004[47]\end{array}$ \\
\hline $\begin{array}{l}\text { Hemodialysis patients } \\
(\mathrm{n}=44)\end{array}$ & Not done & $-44 \%$ vs. control & $\begin{array}{l}\text { Tube formation } \downarrow \\
\text { Migratory capacity } \downarrow\end{array}$ & $\begin{array}{l}\text { Choi } \\
2004[44]\end{array}$ \\
\hline $\begin{array}{l}\text { Kidney graft recipients } \\
(\mathrm{n}=74)\end{array}$ & $\mathrm{CD} 45^{+} / \mathrm{CD} 34^{+} \uparrow$ & $\begin{array}{l}-7 \% \text { vs. control } \\
+45 \% \text { vs. patients with } \\
\text { advanced renal failure }\end{array}$ & $\begin{array}{l}\text { EPC differentiation } \downarrow \\
\text { (effect of uremic serum on EPC } \\
\text { derived from control) }\end{array}$ & $\begin{array}{l}\text { de Groot } \\
2005[49]\end{array}$ \\
\hline $\begin{array}{l}\text { Nocturnal hemodialysis } \\
\text { patients }(\mathrm{n}=10)\end{array}$ & $\begin{array}{l}\mathrm{CD} 34^{+} / \mathrm{VE}-\text { cadherin }^{+} \uparrow \\
\text { compared to conven- } \\
\text { tional hemodialysis }\end{array}$ & Not done & $\begin{array}{l}\text { Migratory capacity } \uparrow \\
\text { compared to conventional } \\
\text { hemodialysis }\end{array}$ & $\begin{array}{l}\text { Chan } \\
2005[50]\end{array}$ \\
\hline $\begin{array}{l}\text { Peritoneal dialysis } \\
\text { patients }(\mathrm{n}=38)\end{array}$ & $\mathrm{CD} 34^{+}$ & $+5 \%$ vs. control & Not done & $\begin{array}{l}\text { Steiner } \\
2005[51]\end{array}$ \\
\hline
\end{tabular}

mellitus types 1 and 2 and hypercholesterolemia were characterized as states of impaired EPC numbers and/or function. At the same time, these conditions are associated with a high risk of atherosclerosis [31-35]. Treatments with statins and PPAR $\gamma$ agonists result in increased numbers of circulating EPCs and an improved function of EPCs [36, 37]. Physical activity has also been shown to enhance EPC numbers and migratory activity in healthy individuals [38].

It is therefore tempting to speculate that EPCs may have regenerative capacity in humans. Further work will be necessary to analyze whether this is some kind of epiphenomenon or a direct causative relationship. Obviously the latter possibility would have enormous therapeutic potential.

\section{Endothelial Progenitor Cells in Different Stages of Chronic Renal Insufficiency}

Chronic kidney disease is a state of endothelial dysfunction, accelerated progression of atherosclerosis and high cardiovascular risk [39, 40]. Circulating ECs - a surrogate marker of endothelial damage - have been shown to be elevated in hemodialysis patients [41]. In addition, the level of circulating ECs was predictive of future vascular events [42]. On this background and given recent observations of EPCs in general, researchers have been keen on studying the numbers and functional properties of EPCs in renal patients.

Nine clinical pilot studies estimating EPC numbers and/or function in different states of renal insufficiency and end-stage renal failure are presently available in the 
literature [43-51]. They are summarized in table 1. A common observation of these studies was an impaired function of cultured EPCs and reduced numbers of CD $34^{+}$ precursor cells counted in peripheral blood (flow cytometric analysis). Potentially contradictory results on the level of EPCs in vitro culture assays in hemodialysis patients were reported by our own group [47]. While Eizawa et al. [43] and Choi et al. [44] reported reduced EPCs, we found them to be elevated. There are two possible explanations for this discrepancy: (a) our study excluded patients with underlying diseases - other than end-stage renal failure - known to be associated with reduced numbers or function of EPCs, and (b) our patients were mostly on erythropoietin; they also had elevated levels of VEGF both known stimuli of EPC mobilization and differentiation.

A positive effect of renal replacement therapy on EPC biology was reported by de Groot et al. [48]. This may be seen as an indication that specific uremic toxins might be responsible for the alterations of EPC numbers/functions. In the same vein it is interesting to note that the same group studied the effects of kidney transplantation on EPC biology. They used a cross-sectional study design [49]. They found that graft function was related to EPC numbers in renal transplant recipients. In a prospective study (unpubl. data) we also found that successful renal transplantation improved EPC function to normal levels. The potential importance of a sufficient removal of uremic toxins was also suggested in a cross-sectional study by Chan et al. [50]. They demonstrated that nocturnal hemodialysis was associated with normal EPC biology. In addition, normal numbers of EPCs were reported by Steiner et al. [51] in patients treated with high-efficiency peritoneal dialysis. In their study the dialysis dose was unusually high (weekly Kt/V 2.47) and the duration of preceding dialysis had been short (median 18 months).

A note of caution as to all of these observations in patients is indicated: the presence of concomitant diseases such as diabetes mellitus, coronary artery disease, chronic heart failure and hyperlipoproteinemia may exert major influence of itself on EPC numbers and function [22, 29-31, 46]. It is often difficult or impossible to separate these potential effects from those of uremia per se. Confounding matters further patients with advanced renal insufficiency are often treated with angiotensin receptor blockers, statins, erythropoietin and thiazolidinediones all known to be stimulating agents of EPCs in humans $[32,41,47,48]$.

Endothelial Progenitor Cells in Chronic Renal Insufficiency

\section{Mechanism of Uremic Dysfunction of Endothelial Progenitor Cells}

In recent experiments, investigators have begun to sort out potential mechanisms responsible for uremic dysfunction of EPCs. In vitro experiments have demonstrated an effect of uremic serum per se to cause EPC dysfunction or to impair differentiation from MNC to EPC [47]. This has promoted a search for individual uremic toxins involved. Candidate substances include parathyroid hormone (PTH), IL-6, homocysteine, $p$-cresol, and others.

In patients with primary hyperparathyroidism the decline of PTH levels after parathyroidectomy was followed by an increase of hematopoietic progenitors [52]. Furthermore, direct effects of PTH on erythropoietin levels have been reported [53]. The latter are a strong stimulus of EPC release from the bone marrow. Successful parathyreoidectomy also increased erythropoietin levels in patients with secondary hyperparathyreoidism. Lastly it is known that an excess of PTH may induce bone marrow fibrosis, a change which may reduce the space available for erythropoiesis $[54,55]$. Since erythrocytes and EPCs share the same precursors it is therefore conceivable that $\mathrm{PTH}$ has negative effects on EPC release from the bone marrow. However, a more direct testing of this potential relationship, e.g. by giving calcimimetics to uremic patients with hyperparathyreoidism, has not been reported yet.

Inflammation is now believed to be a hallmark of chronic renal failure. It would also qualify as a potential contributor to EPC dysfunction in uremia. For comparison in patients with rheumatoid arthritis, the inflammatory state - as determined by IL-6 serum levels - was inversely correlated with EPC numbers [56]. Indeed, in vitro experiments by Verma et al. [57] and Suh et al. [58] support the hypothesis that proinflammatory cytokines impair EPC function and differentiation. Recently Holmen et al. [59] demonstrated a link between inflammatory endothelial cells and EPC dysfunction. In their study EPC proliferation, migration and expression of endothelial cell nitric oxide synthase was inhibited by inflammatory endothelial cells isolated from patients with vasculitis and kidney involvement.

Other uremic toxins may play a role too. For example, the chemically defined uremic toxin homocysteine is known for its inhibitory properties on EPC differentiation and function [60]. $p$-Cresol is a chemically defined uremic toxin with negative impact on $\mathrm{EC}$ migration and wound healing [61]. It is therefore a candidate for interference with EPC biology. Further suggestions of additional candidates will undoubtedly follow as more research of this area become known.

Kidney Blood Press Res 2006;29:24-31 


\section{References}

1 Marsden PA, Goligorsky MS, Brenner BM: Endothelial cell biology in relation to current concepts of vessel wall structure and function. J Am Soc Nephrol 1991;1:931-948.

-2 Asahara T, Masuda H, Takahashi T, et al: Isolation of putative progenitor endothelial cells for angiogenesis. Science 1997;275:964-967.

- 3 Shi Q, Rafii S, Wu MH, et al: Evidence for circulating bone marrow-derived endothelial cells. Blood 1998;92:362-367.

-4 Peichev M, Naiyer AJ, Pereira D, et al: Expression of VEGF-R2 and AC133 by circulating human $\mathrm{CD} 34^{+}$cells identifies a population of functional endothelial precursors. Blood 2000; 95:952-958.

5 Szmitko PE, Fedak PWM, Weisel RD, et al: Endothelial progenitor cells. New hope for a broken heart. Circulation 2003;107:30933100.

-6 Hristov M, Erl W, Weber PC: Endothelial progenitor cells. Mobilization, differentiation, and homing. Arterioscler Thromb Vasc Biol 2003;23:1185-1189.

7 Aicher A, Zeiher AM, Dimmeler S: Mobilizing endothelial progenitor cells. Hypertension 2005;45:321-325.

-8 Matsubara H: Risk to the coronary arteries of intracoronary stem cell infusion and G-CSF cytokine therapy. Lancet 2004;363:746-747.

-9 Harraz M, Jiao C, Hanlon HD, et al: CD34blood-derived human endothelial cell progenitors. Stem Cells 2001;19:304-312.

10 Urbich C, Heeschen C, Aicher A, et al: Relevance of monocytic features for neovacularization capacity of circulating endothelial progenitor cells. Circulation 2003;108:2511-2516.

-11 Zhao Y, Glesne D, Hubermann E: A human peripheral blood monocyte-derived subset acts as pluripotent stem cells. Proc Natl Acad Sci USA 2003; 100:2426-2431.

12 Rehmann J, Li J, Christie MO, et al: Peripheral blood endothelial progenitor cells are derived from monocyte/macrophages and secrete angiogenic growth factors. Circulation 2003; 107:1164-1169.

-13 Nowak G, Karrar A, Holmen C, et al: Expression of vascular endothelial growth factor receptor-2 or tie-2 on peripheral blood cells defines functionally competent cell populations capable of reendothelialization. Circulation 2004;110:3699-3707.

14 Romagnami P, Annunziato F, Liotta F, et al: $\mathrm{CD} 14^{+} \mathrm{CD} 34^{\text {low }}$ cells with stem cell phenotypic and functional features are the major source of circulating endothelial progenitors. Circ Res 2005;97:314-322.

15 Oswald J, Boxberger S, Jorgensen B, et al: Mesenchymal stem cells can be differentiated into endothelial cells in vitro. Stem Cells 2004;22: 377-384.

16 Ziegelhoeffer T, Fernandez B, Kostin S, et al: Bone marrow-derived cells do not incorporate into the adult growing vasculature. Circ Res 2004;94:230-238.
17 Heil M, Ziegelhoeffer T, Mees B, et al: A different outlook on the role of bone marrow stem cells in vascular growth. Bone marrow delivers software not hardware. Circ Res 2004;94:573574.

18 Wagers AJ, Sherwood RI, Christensen JL, et al: Little evidence for developmental plasticity of adult hematopoietic stem cells. Science 2002;297:2256-2259.

19 Hillebrands JL, Klatter FA, van Dijk WD, et al: Bone marrow does not contribute substantially to endothelial-cell replacement in transplant Atherosclerosis. Nat Med 2002;8:194195.

-20 Urbich C, Dimmeler S: Endothelial progenitor cells. Characterization and Role in vascular biology. Circ Res 2004;95:343-353.

21 Kalka C, Masusa H, Takahashi T, et al: Transplantation of ex vivo expanded endothelial progenitor cells for therapeutic neovascularization. Proc Natl Acad Sci USA 2000;97: 3422-3427.

-22 Agbulut O, Vandervelde S, Attar NA, et al: Comparison of human skeletal myoblasts and bone marrow-derived $\mathrm{CD} 133^{+}$progenitors for the repair of infarcted myocardium. J Am Coll Cardiol 2004:44:458-463.

23 Kawamoto A, Gwon HC, Iwaguro H, et al: Therapeutic potential of ex vivo expanded endothelial progenitor cells for myocardial ischemia. Circulation 2001;103:634-637.

$\checkmark 24$ Assmus B, Schachinger V, Teupe C, et al: Transplantation of progenitor cells and regeneration enhancement in acute myocardial infarction (TOPCARE-AMI). Circulation 2002; 106:3009-3017.

25 Griese DP, Ehsan A, Melo LG, et al: Isolation and transplantation of autologous circulating endothelial cells into denuded vessels and prosthetic grafts: implications for cell-based vascular therapy. Circulation 2003;108:27102715.

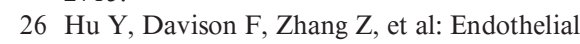
replacement and angiogenesis in atherosclerotic lesions of allografts are contributed by circulating progenitor cells. Circulation 2003;108: 3056-3058.

27 Walter DH, Rittig K, Bahlmann FH, et al: Statin therapy accelerates reendothelialization: a novel effect involving mobilization and incorporation of bone marrow-derived endothelial progenitor cells. Circulation 2002;105: 3017-3024.

28 Rauscher FM, Goldschmidt-Clermont PJ, Davis $\mathrm{BH}$, et al: Aging, progenitor cell exhaustion, and atherosclerosis. Circulation 2003;108: 457-463.

29 Hill JM, Zalos G, Halox JP, et al: Circulating endothelial progenitor cells, vascular function, and cardiovascular risk. N Engl J Med 2003; 348:593-600.

30 Vasa M, Fichtlscherer S, Aicher A, et al: Number and migratory activity of circulating endothelial progenitor cells inversely correlate with risk factors for coronary artery disease. Circ Res 2001;89:E1-E7.
31 Heiss C, Keymel S, Niesler U, et al: Impaired progenitor cell activity in age-related endothelial dysfunction. J Am Coll Cardiol 2005;45: 1441-1448.

- 32 Kondo T, Hayashi M, Takeshita K, et al: Smoking cessation rapidly increases circulating progenitor cells in peripheral blood in chronic smokers. Arterioscler Thromb Vasc Biol 2004;24:1442-1447.

33 Loomans CJ, de Koning EJ, Staal FJ, et al: Endothelial progenitor cell dysfunction: a novel concept in the pathogenesis of vascular complications of type 1 diabetes. Diabetes 2004;53: 195-199.

34 Tepper OM, Galiano RD, Capla JM, et al: Human endothelial progenitor cells from type II diabetics exhibit impaired proliferation, adhesion, and incorporation into vascular structures. Circulation 2002;106:2781-2786.

35 Chen J, Zhang F, Tao Q, et al: Number and activity of endothelial progenitor cells from peripheral blood in patients with hypercholesterolemia. Clin Sci (Lond) 2004;107:273-280.

36 Dimmeler S, Aicher A, Vasa M, et al: HMGCoA reductase inhibitors (statins) increase endothelial progenitor cells via the PI3-kinase/ Akt pathway. J Clin Invest 2001;108:391397.

37 Pistrosch F, Herbrig K, Oelschlaegel U, et al: PPAR gamma-agonist rosiglitazone increases number and migratory activity of cultured endothelial progenitor cells. Atherosclerosis 2005; 183:163-167.

38 Laufs U, Urhausen A, Werner N, et al: Running exercise of different duration and intensity: effect on endothelial progenitor cells in healthy subjects. Eur J Cardiovasc Prev Rehabil 2005;12:407-414.

39 Passauer J, Büssemaker E, Range, et al: Evidence in vivo showing increase of baseline nitric oxide generation and impairment of endothelium-dependent vasodilatation in normotensive patients on chronic hemodialysis. J Am Soc Nephrol 2000;11:1726-1734.

40 Foley RN, Parfrey PS, Sarnak MJ: Epidemiology of cardiovascular disease in chronic renal disease. J Am Soc Nephrol 1998;9(suppl):S16S23.

41 Koc M, Bihorac A, Segal MS: Circulating endothelial cells as potential markers of the state of the endothelium in hemodialysis patients. Am J Kidney Dis 2003;42:704-712.

42 Koc M, Richards HB, Bihorac A, et al: Circulating endothelial cells are associated with future vascular events in hemodialysis patients. Kidney Int 2005;67:1078-1083.

43 Eizawa T, Murakami Y, Matsui M, et al: Circulating endothelial progenitor cells are reduced in hemodialysis patients. Curr Med Res Opin 2003; 19:627-633.

44 Choi JH, Kim KL, Huh W, et al: Decreased number and impaired angiogenic function of endothelial progenitor cells in patients with chronic renal failure. Arterioscler Thromb Vasc Biol 2004;24:1246-1252. 
45 Bahlmann FH, de Groot K, Spandau JM, et al: Erythropoietin regulates endothelial progenitor cells. Blood 2004;103:921-926.

-46 Bahlmann FH, de Groot K, Duckert T, et al: Endothelial progenitor cell proliferation and differentiation is regulated by erythropoietin. Kidney Int 2003;64:1648-1652.

- 47 Herbrig K, Pistrosch F, Oelschlaegel U, et al: Increased total number but impaired migratory activity and adhesion of endothelial progenitor cells in patients on long-term hemodialysis. Am J Kidney Dis 2004;44: 840-849.

48 De Groot K, Bahlmann FH, Sowa J, et al: Uremia causes endothelial progenitor cell deficiency. Kidney Int 2004;66:641-646.

-49 De Groot K, Bahlmann FH, Bahlmann E, et al: Kidney graft function determines endothelial progenitor number in renal transplant recipients. Transplantation 2005;79:941-945.

>50 Chan CT, Li SH, Verma S: Nocturnal hemodialysis is associated with restoration of impaired endothelial progenitor cell biology in end-stage renal disease. Am J Physiol Renal Physiol 2005;289:F679-F684.
51 Steiner S, Schaller G, Puttinger H, et al: History of cardiovascular disease is associated with endothelial progenitor cells in peritoneal dialysis patients. Am J Kidney Dis 2005;46: 520-528.

52 Kotzmann H, Abela C, Heindl J, et al: Effect of successful parathyreoidectomy on hematopoietic progenitor cells and parameters of red blood cells in patients with primary hyperparathyreoidism. Horm Metab Res 1997;29:387392.

53 Urena P, Eckardt KU, Sarfati E, et al: Serum erythropoietin and erythropoiesis in primary and secondary hyperparathyreoidism. Effect of parathyreoidectomy. Nephron 1991;59: 384-393.

54 Brickmann AS, Sherrard DJ, Jowsey J: Effect of 1,25 dihydroxy-cholecalciferol on skeletal lesions and plasma parathyreoid hormone in uremic osteodystrophy. Arch Intern Med 1974; 134:883-888.

55 Rao DS, Shih MS, Mohini R: Effect of serum parathyreoid hormone and bone marrow fibrosis on the response to erythropoietin in uremia. N Engl J Med 1993;328:171-175.

$\checkmark 56$ Herbrig K, Haensel S, Oelschlaegel U, et al: Endothelial dysfunction in patients with rheumatoid arthritis is associated with a reduced number and impaired function of endothelial progenitor cells. Ann Rheum Dis 2006;65: 157-163.
57 Verma S, Kuliszewski MA, Li SH, Szmitko PE, Zucco L, Wang $\mathrm{CH}$, et al: C-reactive protein attenuates endothelial progenitor cell survival, differentiation, and function: further evidence of a mechanistic link between C-reactive protein and cardiovascular disease. Circulation 2004; 109:2058-2067.

58 Suh W, Kim KL, Choi JH, Lee YS, Lee JY, Kim JM, et al: C-reactive protein impairs angiogenic functions and decreases the secretion of arteriogenic chemocytokines in human endothelial progenitor cells. Biochem Biophys Res Commun 2004;321:65-71.

>59 Holmen C, Elsheikh E, Stenvinkel P, et al: Circulating inflammatory endothelial cells contribute to endothelial progenitor cell dysfunction in patients with vasculitis and kidney involvement. J Am Soc Nephrol 2005;16: 3110-3120.

60 Chen JZ, Zhu JH, Wang XX, et al: Effects of homocysteine on number and activity of endothelial progenitor cells from peripheral blood. J Mol Cell Cardiol 2004;36:233-239.

61 Dou L, Bertrand E, Cerini C, et al: The uremic solutes $p$-cresol and indoxyl sulfate inhibit endothelial proliferation and wound repair. Kidney Int 2004;65:442-451. 